\title{
EDITORIAL
}

\section{A New Journal with a Long Tradition}

Sixty years ago, in 1959, the Belgian Political Science Institute launched the first issue of Res Publica. Today, Politics of the Low Countries (PLC) steps forward as its proud successor. For the first time in the journal's history, it will be published entirely in English, aka the lingua franca of science. However, the shift to English is only the most recent language shift; until the end of the 1970s Res Publica was the journal of the Belgian political scientists and was published mainly in French. In those days even French superstars of political science, Maurice Duverger and Raymond Aron, wrote articles for the journal. Especially in the initial years of the journal only 'francophone' (or French) contributions appeared. It was not until 1962 that the first article in Dutch (or 'Flemish') was published, but, initially, this was more the exception than the rule. The number of Dutch contributions then gradually increased and Res Publica became a real bilingual journal.

A change came about in 1978, when Wilfried Dewachter became editor-in-chief of the journal, and Res Publica became the academic outlet mainly (but not solely) for Dutch-speaking political scientists in Belgium. The number of francophone articles decreased continuously, and in 2006 the last scientific contribution in French was published. When the editors of Res Publica decided, in 2008, to collaborate with the Dutch Political Science Association (NKWP), this sealed the 'Dutchification' of the journal. In the last decade Res Publica has decided to publish articles only in Dutch, a decision that created a language barrier for the upcoming francophone scene of political scientists who also studied politics in the Low Countries. The transformation of Res Publica to Politics of the Low Countries makes it possible to involve scholars working on politics in the Low Countries in the francophone part of Belgium and in Luxembourg, but also in the rest of the world.

That said, the choice of English as the language of publication of the journal is a pragmatic and not a romantic one. On the one hand, it feels uncomfortable that scholars can no longer communicate about their research in their own language. Some feel that it weakens the link between academics, political practitioners, the broader public and the students. Indeed, there is merit to this argument: we must prevent a language gap from arising in our academic system, as it may lead to a social gap. For early career scholars, in particular, the threshold for submitting first articles to a journal must be kept low. On the other hand, it is masochistic to sacrifice the understanding of politics in the Low Countries on the altar of a sort of cultural nationalism. The low countries constitute interesting cases from an international perspective, and for this reason we feel that there is a need to give an international audience access to studies focusing specifically on these countries. Moreover, more and more scholars outside the Low Countries conduct interesting research on the Belgian, Dutch or the Luxembourg cases. It would be a 
pity to miss out on their valuable insights into this matter. Obviously, this does not relieve political scientists of the duty to translate their research for the broader public.

The latter also obliges us to increase our online visibility. Next to the choice of English, the editorial board wanted to optimize the digital accessibility of the journal. This includes easy online access to current and future issues and a better archive of all the issues of the journal (including some recent volumes of Res Publica). On the website of the journal we will also provide free open access for one article in every issue, to help scholars specializing in the politics of the Low Countries to increase their academic visibility. The new publisher of the journal (Eleven International Publishing) will also submit the journal to appropriate abstract- and indexing services.

Further innovations are a sharper focus on all the Low Countries, including Luxembourg, new journal sections and new partners. PLC wants to provide scientific insights into Belgian, Dutch and Luxembourg politics. It is now the official journal of the Flemish (VPW), Francophone (ABSP) and Luxembourg (LuxPol) political science associations in cooperation with the Dutch Political Science Association (NKWP).

The journal has a comprehensive scope, embracing all the major political developments in Belgium, The Netherlands and Luxembourg. PLC publishes research articles from a wide variety of methodological perspectives and on a broad range of topics such as political behaviour, political parties, political communication, parliamentary studies, public administration, political philosophy and even EUand international politics. All these areas of study are considered in relation to Belgium, the Netherlands or Luxembourg. These countries can be studied either as specific case studies or as part of comparative research. Apart from research articles, PLC also provides space for descriptive research notes on politics in the Low Countries, $\mathrm{PhD}$ reviews and literature reviews on the academic evolutions within political science in Belgium, The Netherlands and Luxembourg. In sum, this makes Politics of the Low Countries essential reading for both political practitioners and academics.

The first issue of PLC is a tribute to probably the best known and influential political scientist with roots in the Low Countries: Arend Lijphart. Twenty years ago he published his seminal work, Patterns of Democracy, in which he proved that consensus democracy is more democratic than majoritarian democracy in most respects. Belgium, The Netherlands and Luxembourg are, according to Lijphart, good examples of consensus democracies. It is for this reason that this special issue explores the extent to which the Low Countries can still be regarded as prototypical cases.

This is done, first of all, from the perspective of political science. Van Haute and Wauters assess the extent to which parties in Belgium still share the internal characteristics of parties in consensus democracies. In two other articles, scholars from public policy and public administration test the current value of Lijphart's work. Van der Meer, Van den Berg, Van Dijck, Dijkstra and Steen deplore Lijp- 
hart's lack of attention to the role of the bureaucratic system in his assessment of democracies. They expand the model of Lijphart with seven additional features and look at what this amended scale means for Belgium and the Netherlands. Hemerijck and Van Kersbergen test the hypothesis that consensus democracies are kinder welfare states and argue that this claim remains relevant. This is illustrated with welfare-state reform experiences in the Netherlands and Belgium. Finally, for their literature review Van der Meer (Tom) and Kern were inspired by the claim of Lijphart that citizens tend to be more satisfied with democracy in consensual democracies. Taking stock of the literature on consensualism and political support, they come to the conclusion that the expanded literature on this theme is more ambiguous about the advantage of consensus democracy now than it was twenty years ago.

Enjoy reading.

\section{On behalf of the editorial board:}

Nicolas Bouteca (editor-in-chief), Stefanie Beyens, Katja Biedenkopf, Annelien de Dijn, Silvia Erzeel, Jonas Lefevere, Christophe Lesschaeve, Brenda Van Coppenolle, Julien van Ostaaijen, Min Reuchamps, Peter Thijssen, Daphne van der Pas, Lorenzo Terrière (editorial assistant). 